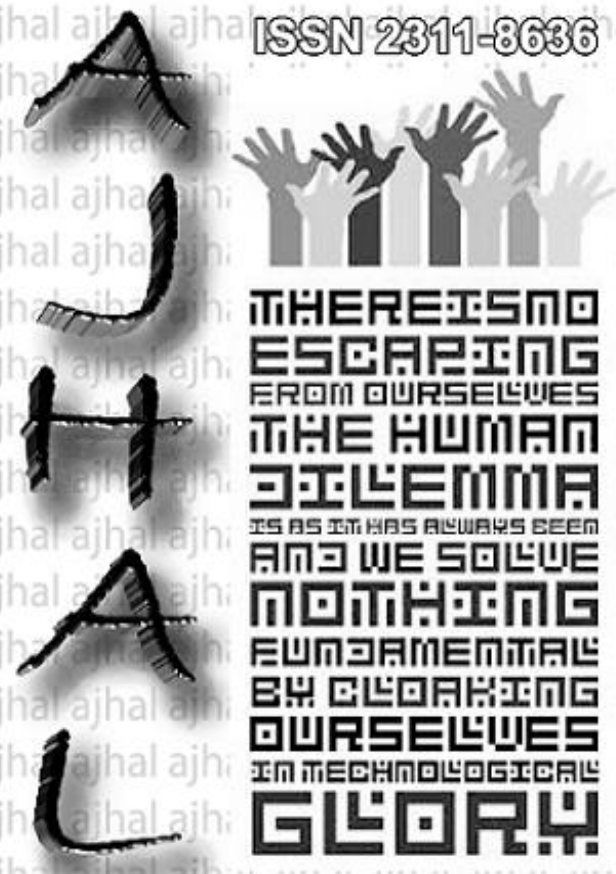

Vol 3, No. 2/2016

Asjan Journal of Humanity, Art and Liteigatul"e 


\section{Universe in Movement}

\section{Humberto Ortega-Villaseñor ${ }^{1 *}$, Alonso Santiago Ortega González ${ }^{2}$}

${ }^{1}$ Professor, Department of Literary Studies, Universidad de Guadalajara, Sierra de Tapalpa 1336 (entre Cuicuilco e Ixtépete), Col. Pinar de la Calma, Zapopan, Jalisco, MÉXICO

${ }^{2}$ Department of Physics, Universidad de Guadalajara, Sierra de Tapalpa 1336 (entre Cuicuilco e Ixtépete), Col. Pinar de la Calma, Zapopan, Jalisco, MÉXICO

ISSN: 2311-8636 (Print)

ISSN: 2312-2021 (Online)

DOI prefix: 10.18034

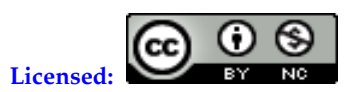

Source of Support: Nil

Conflict of Interest: None Declared

${ }^{*}$ Email for correspondence:

huorvi@gmail.com

\section{ABSTRACT}

In this paper, we analyze some aspects of the posthumous work of American writer Edgar Alan Poe, titled Eureka. A prose poem, published in 1848. This is a controversial book for several reasons, among others, by the complexity of its artistic characterization, depth of and cognitive influences and impact of its nutrients for the world of science, especially physics and astronomy. First, we proceed to do a panoramic review of the contributions of the writer outside the United States, and it is explained the interest in his vast literary production in France and in the Spanish-speaking world. They are then analyzed the links that Eureka may have with the literary career of Poe and other fields of culture, art and science that are related precisely with philosophy, aesthetics and above all, the Astronomy of his time. Finally, it is considered and weighted the prospective dimension of the work under study, trying to clarify to what extent Eureka is ahead of the universe conception that we have today and what effect it may have had on the contemporary scientific and technological change.

Key Words: complexity, universe, poetry, image, concept, space, time

\section{Background and Context: Poe In the Literary Cosmos}

Edgar Allan Poe was an exceptional writer from the United States. He was born on January 19, 1809 in Boston, Massachusetts, and died at the age of 40. He was a prolific man-of-letters: poet, critic, and romantic journalist, known as one of the world's greatest short-story writers - he was a pioneer of the genre in his native country. As an innovator of the gothic novel, he is primarily remembered for his tales of terror, his detective stories, and for a handful of works from the emerging genre of science fiction.

The 200th anniversary of his birth was celebrated on five continents in 2009. As Emron Esplin observes, recognition of Poe's influence in the world is overdue, along with the world's influence on the contemporary image of Poe (2011: 198), thanks to the interest that several renowned writers had in translating his work. According to Esplin, Poe was scarcely recognized in his land (the United States) for almost 100 years. In other countries, however, his work caught the eye of critics and was published extensively, first by the French in the 19th century, and then by Latin Americans and scholars from other countries throughout the 20th. Esplin points out: 
Along with the admiration of Baudelaire and Cortázar, Poe's work has found advocates in several languages and literatures, and quite often, these supporters themselves are considered to be some of the most influential writers of their various national or regional traditions. Three of France's most important poetsBaudelaire, Stephane Mallarme, and Paul Valery-translated and/or championed Poe in their own writings; Lu Xun, one of the fathers of modern Chinese literature, literally brought Poe to China by sending a copy of "The Gold-Bug" to his brother Zhou Zuo-ren from Japan (Ning and Stauffer 149); Machado de Assis, often considered Brazil's most important writer, translated "The Raven" into Portuguese and spread Poe's themes and techniques through several of his own fictional works; famed Portuguese poet Fernando Pessoa also translated "The Raven"; and this list could continue on. (Esplin, 2011 : 200).

Subsequently, thanks to the translation and publication efforts undertaken in the Spanishspeaking world primarily by Darío, Julio Cortázar, Jorge Luis Borges and Horacio Quiroga, Poe's work became even better known in the 20th century. Esplin chronicles the process:

By offering his readers access to all of Poe's major prose, Borges's fellow Argentine, Julio Cortazar, accomplished for the Spanish-speaking world of the twentieth century what Baudelaire had done for the French in the nineteenth century. Before Cortazar, several of Poe's fictional works had been translated into Spanish, but no single translator had taken on all of Poe's short stories. In 1956, Cortazar published a two-volume set of Poe's prose with the University of Puerto Rico and with RevistadelOccidente in Madrid entitled Obrasenprosa. Fourteen years later, Cortazar published with Alianza Editorial a revised version of his translations of the published stories in another two-volume set under the title Cuentos. In 1968, Cortazar translated Poe's only novel as Aventuras de Arthur Gordon Pym, and in 1972 he tackled Poe's cosmological Eureka. (Esplin, 2011: 201).

It was thus Cortázar's efforts as a translator that gave Spanish-language readers access to a prose work of Poe's that they had never been able to enjoy before. Cortázar also had an impact on Poe's public image by publishing a brief biography called "The Life of Edgar Allan Poe" as a prologue to the 1956 edition of Prose Works.

In this prologue, Cortázar described a Poe more in line with Hervey Allen's Israfel, The Life and Times of Edgar Allan Poe than with three of the more popular renditions of Poe's life previously available in Spanish- “Edgar Poe suvida y susobras" (the Spanish title used for the translation of Baudelaire's famous prologue "Edgar Allan Poe: sa vie et ses oeuvres"), Dario's "Los raros," and Armando Bazan's prologue for a popular collection of Poe's tales from various translators in Spanish entitled Obras completes de Poe from 1944-which heavily romanticized Poe's life and cast him as a decadent and/or tragic persona whose primary muse was alcohol. (Esplin, 2011: 202).

Cortázar views Poe as tormented by inner demons rather than inspired by alcohol. He draws a more human portrait of Poe-a brilliant writer struggling openly with addictions and personal problems that frustrate his projects much more than they provide him with any kind of inspiration. Cortázar's prologue has been published widely and appears with 
the numerous reprints of his translations that have come out since 1956 up to the recent annotated edition of 2008/2009. Cortázar's biography continues to offer a refreshing counterweight to Baudelaire's vision of Poe that was so famous in Latin America from the mid-19th century to the mid-20th. (Esplin, 2011: 202).In this paper, the constant comparison between the original text and translation of Eureka made by Julio Cortázar has helped us to maintain required objectivity and to clarify more rigorously the meaning of the work.

\section{Cosmic Poem: ANALYsis of EUREKA}

Eureka is a book of assorted associations, links and reconciliations, matter and spirit, the universe, poetry and painting, an aesthetic imbued with spiritual categories (Elizabeth Vincelette, 2008: 41).

As expressed by José Luis Penón, it is a work in which we can see the relationship between the philosophy of life of the author and his lettered philosophy. "This is the strongest expression of his materialistic side and of his spiritual one that eventually will close the circle of connections between Poe human being and Poe artist (2013: 38). The title of the work (Eureka, A Prose Poem), would raise bitter criticism from literary experts of the time, as poetic prose was less prevalent in the universal lyrical and had been maligned (Penón, 2013: 40).

As we know, in the book of Scott Peeples (2004), is done a comprehensive compilation of criticism of Poe's work. Most of the critics build their negative arguments in relation Eureka assuming that it is a scientific essay. They conclude that what is stated in Eureka is founded on mere suppositions or simply on something that they qualify as a hoax or a joke. A joke that could not have been taken seriously by the American society of the nineteenth century, being deeply Puritan and religious (Penón, 2013: 40). In fact, from the second decade of the twentieth century, something like the modern academic criticism of the work of Poe would emerge, based upon psychoanalytic criticism, formalism and deconstruction, socio-historical criticism and biography.

In the preamble to Eureka Poe presents the work as a "Book of Truths, not in its character of Truth-Teller, but for the Beauty that abounds in its Truth; constituting it true" (1848: 7), in his words.

-to the dreamers and those who put faith in dreams as in the only realities [...] To these I present the composition as an Art-Product alone:-let us say as a Romance; or, if I be not urging too lofty a claim, as a Poem. What I here propound is true:- - therefore it cannot die:- or if by any means it be now trodden down so that it die, it will "rise again to the Life Everlasting." Nevertheless it is as a Poem only that I wish this work to be judged after I am dead. (Poe, 1848: 7).

By declaring it a "book of truths," Poe gives the text an almost Biblical importance, although he is careful to warn that Eureka is true not because it tells the actual truth, but because of the beauty of the truth that its logic leads to. As Elizabeth Vincelette says, "in this formulation it is beauty that makes Eurekatrue, because it constructs itself at the same time it is constructed by truth itself. This is one of the many paradoxes put forth by Poe" (2008: 36). 
As she points out herself, even though Eureka in its religiosity admits the possibility of a genuine reading, the option of taking the work as sincere and not satirical depends on accepting Poe as a good narrator (Vincelette, 2008: 37). He wants to touch and move his audience intellectually and spiritually, and to this end, Poe's new type of narrator is Poe himself, a being endowed with higher powers of perception than those of other narrators of the same author (who titillate their readers with tales of perversity). In the preface to Eureka Poe expects the readers, his audience, to receive the work as true, but as a different kind of truth from that proclaimed by his contemporaries (Vincelette, 2008: 37).

Like Kierkegaard, Poe adopts an almost oracular voice to challenge the narrowness of intellectual methodology, the tendency to categorize all reasoning processes as either inductive or deductive, a priori or a posteriori. He insists that reasoning should not be limited to propositions such as "and/or" (the exact opposite of the existentialist option set forth by the Danish philosopher in his work Either/Or). (Kierkegaard, 1987a).

As the poet-philosopher-prophet puts it, Poe reworks the history of cosmology to create a new theology, a mixture of classical Greek and Judeo-Christian tradition. And paradox is the quintessence of this theology, and thus the reading of Eureka, like one of Poe's cryptograms or puzzles, determines the dialectic contained in them. The discovery of Eureka's truth requires embracing that paradox (Vincelette, 2008: 37).

I propose to take such a survey of the Universe that the mind may be able really to receive and to perceive an individual impression. He who from the top of Ætna casts his eyes leisurely around, is affected chiefly by the extent and diversity of the scene. Only by a rapid whirling on his heel could he hope to comprehend the panorama in the sublimity of its oneness. But as, on the summit of Ætna, no man has thought of whirling on his heel, so no man has ever taken into his brain the full uniqueness of the prospect; and so, again, whatever considerations lie involved in this uniqueness, have as yet no practical existence for mankind. (Poe, 1848: 9).

The plot in both cases-in the story and in Eureka-resorts to two characters, Aries Tottle (Aristotle) and Hog (Bacon), to criticize Aristotelian deduction and Baconian induction, because they reveal the insufficiency of their resources to comprehend the Universe:

The savans contenting themselves with proscribing all other competitors, past, present, and to come; putting an end to all controversy[12] on the topic by the promulgation of a Median law, to the effect that the Aristotelian and Baconian roads are, and of right ought to be, the solo possible avenues to knowledge:'Baconian,'[...] "Now I do assure you most positively"-proceeds the epistle"that I represent these matters fairly; and you can easily understand how restrictions so absurd on their very face must have operated, in those days, to retard the progress of true Science, which makes its most important advances-as all History will show-by seemingly intuitive leaps. (Poe, 1848: 12).

Poe implicitly argues that contradictions are the essence of truth due to their proximity to circular reasoning. He beholds beauty in contrary-diction, i.e., in opposing, in speaking against. As Vincelette puts it: 
Poe sees beauty in contra-diction, in speaking against, revealing his belief in the spiritual unification of aesthetics and science. The satire of "Aries Tottle" questions Aristotle's statements about God and the universe; the "real" Aristotle felt that the universe had very little "direct bearing on any belief in the existence of god" (2008: 37) and was "non-committal" about it. But Poe is anything but noncommittal. He depends on Greek/Ptolemaic cosmology, which had been modified in medieval philosophy to be "compatible" with Judeo-Christian theology. (2008: 38)

In this sense it would seem that Poe anticipated certain observations made a century and a half later by the piercingly critical philosopher of science, Karl Popper. This Austrian thinker maintained that while the objectives of art and science are evidently differentscience seeks truth and art seeks perfection - art can also be seen or considered as a field for problem-solving, for exploring new concepts, for confronting these concepts with others, for coming up with multiple solutions to one and the same problem, etc. (OrtegaVillaseñor, 2003: 238).

Naturally, art has its own problems and ways of solving. And yet there is an additional analogy: just as in science, in the development of art, which runs its course from one problem to another, the critical analysis method used for solving the problems plays a key role [...] The application of critical analysis explains why the creator can go beyond his own potential and produce a work that transcends the limitations that characterize him (Popper quoted by ElzbietaPietruska-Madej, 2001: 37).

Popper argues that the trial-and-error method is what explains the evolution of models, artistic proposals and value systems typical of all fields or expressions of art. He feels that those who defend a notion of art as the simple manifestation or expression of the artist's emotions tend to advocate a mechanical interpretation of the method and of the process of creation itself. Popper always resisted accepting the expressionist theory of art that claimed that the essence of art was the artist's expression of her personality, her inner condition or her feelings (Ortega-Villaseñor, 2003: 240).

According to Vincelette, Edgar Allan Poe saw science and art as imitating each other, with the poet as observer. It is up to both the poet and the scientist to explain the Universe, and many of the characters in Poe's stories reflect this belief. For example, AugusteDupin represents the poet and the scientist at the same time, urging the narrator of The Murders in the Rue Morgue to point out that "the ingenious are always fanciful, and the truly imaginative never otherwise than analytic" (Vincelette, 2008: 38). Thus, the Minister in the story speaks of Dupin in the following terms:

"As a poet and mathematician, he would reason well; as a mere mathematician, he could not have reasoned at all" (P\&T, 691)... As Benjamin Fisher argues, "Poe's primary objection to science was that it often appeared, inaccurately, as the term for workings of unrelenting logic or of eighteenth-century mechanistic philosophy," both of which denied "imagination any importance in the ordering of the world's thinking." Like the opening letter to Eureka, "Sonnet to Science" concerns itself with faulty reasoning and the imposition of empiricism on poetic thought, the devaluing of poetry in the Enlightenment mind (Vincelette, 2008 : 38) 
Poe bases his thinking on the primacy of perception as the threshold or gateway to intuition, once again aligning himself with the Romantic sensitivity (Vincelette, 2008: 40). According to Vincelette, by defining Eureka as not only a poem but a loving poem, Poe offers a text that is concerned with intuition, perception and transformation. Curtis Brooks states that Poe, without the help of Platonic or idealist thinking, proposed reconciling his mechanistic universe (matter) with his poetry (spirit), i.e., turning choice, 'either poetry or science,' into the conjunction that links the two, poetry and science" (quoted by Vincelette, 2008: 40).

Of course, no one will suppose that I here contend for the absolute impossibility of that which we attempt to convey in the word "Infinity." My purpose is but to show the folly of endeavoring to prove Infinity itself or even our conception of it, by any such blundering ratiocination as that which is ordinarily employed. Nevertheless, as an individual, I may be permitted to say that I cannot conceive Infinity, and am convinced that no human being can. A mind not thoroughly self-conscious-not accustomed to the introspective analysis of its own operations-will, it is true, often deceive itself by supposing that it has entertained the conception of which we speak. (Poe, 1848: 25-26).

\section{THE BOWL OF SUSTENANCE: ONLY BEAUTY, ONLY ORDER}

What then is Eureka? What does it represent or mean at its deepest level? Poe proclaims his truths with metaphors and myths. Barbara Cantalupo warns us that Poe creates his version of the Universe by setting it down in language, applying Barthes' linguistic definition of the performative in Eureka - in the sense of the full conjunction of the sentence and the perfect action (1990: 87).

Some analysts of Edgar Allan Poe's work, especially those bent on doing in-depth analysis of his novel and tales of terror in the 19th and 20th centuries, could never fully 'digest' a contribution of the scope of Eureka. His biographers and critics could not grasp such an eccentric work, so removed from the area of his interests and from his style after his wife's death. Much recent research, however, from multiple perspectives has begun to appreciate not only the sources that Poe drew upon to write it, but also the mettle he showed in going forward with it and that led him to look back on it as the high-water mark of his work as a modern writer, a text that crosses the boundaries of science and knocks at the gate of the realm of fiction.

Isaac Courtney Fugate is a sharp-eyed researcher who has scrutinized Eurekathoroughly from a philosophical perspective, at a certain remove from the analyses we have come to expect from Poe scholars. Fugate simultaneously tracks down the philosophical currents that might have inspired Poe's work and weaves together the miracles that this little book signified for the world of Art and Science.

In the years before Poe's birth, the German philosopher FWJ Schelling (1775-1854) argued that all true science and poetry merge into a single activity in our contemplations of the original unity and source of all things. He was drawing on an even older tradition dating back to Nicholas of Cusa (1401-1464) and passing through Giordano Bruno, Leibniz and Kant, Schelling himself and then Coleridge, von Humboldt and others. In this tradition, the origin, nature and destiny of human beings themselves were seen as identical to those of the cosmos. 
I will argue that Poe's Eureka draws upon this same tradition both directly and indirectly while reformulating its central ideas in accordance with Poe's own philosophical insights and aesthetics sensibilities (Fugate, 2012: 109) [...] My argument is that Eureka can be read profitably and responsibly as a contribution to the metaphysical cosmology that was advanced in Germany through the work of Kant and Schelling. I am also convinced that once this is recognized, many puzzling aspects of Eureka will be clarified and, as a consequence of this, the perceived necessity to discover a less straightforward meaning for Poe's work, which is now prevalent in the secondary literature, will be greatly diminished.

To achieve this end, I will draw attention to a number of similarities that show that Poe's work belongs to the same tradition of philosophical cosmology. While there are many other important points of contact between Poe and Schelling in particular, I will focus in this paper exclusively on those related to the intersection between their ideas on the systematic constitution of the universe and on proper scientific and poetic method. As we will see, here lies perhaps the most characteristic feature of German cosmological thought. (Fugate, 2012:109-110).

With his in-depth analysis of Eureka, Fugate opens a window on an almost incredible world of similarities in the concerns that gave rise to Eureka, to Kant's Critique of Pure Reason, and to Schelling's proposal. Eureka, as Poe himself declared, is a metaphysical poem in the fullest sense of the word. Poe tells us from the beginning that he will be discussing the physics, metaphysics and mathematics of the Universe, its material and spiritual dimensions; "its Essence, its Origin, its Creation, its Present Condition and its Destiny." In developing this discourse, "Poe later reminds the reader that he is "aiming less at physical than at metaphysical order'" (109). As we saw earlier:

Poe is careful to employ not in its physical, but in its broader metaphysical sense, asdescribing an individual, orderly and beautiful whole of all being, and thus as containing what is possible, what is actual, what is material, what is spiritual, what is past, present and future in a word," that all inclusive and absolute Kosmos" (Fugate, 2012:109).

And Kant is the philosopher who almost 100 years earlier legitimized the search for truth in the subject's very personal musings.

At the heart of Eureka there lies a very specific conception of the structure of the cosmos, one that is not found in either ancient or medieval cosmological theories. Although its roots lie in earlier thinkers like Cusa, Copernicus and Bruno, its first detailed expression is found in the writings of Immanuel Kant (Fugate, 2012 : 110). 'When one considers that nature and the eternal laws that are prescribed for the reciprocal influence of its substances are not a self-sufficient principle that would be necessary in the absence of God (Kant, quoted by Fugate, 2012: 110).

The essence of all things must have its common origin in a certain fundamental being (Kant, quoted by Fugate, 109 and 110). For this reason, visible, palpable harmonic relations emerge among them because their attributes have their origin in a single source of higher knowledge or understanding. 
"We know absolutely nothing of the nature or essence of God:-in order to comprehend what he is, we should have to be God ourselves." "We should have to be God ourselves!"-With a phrase so startling as this yet ringing in my ears, I nevertheless venture to demand if this our present ignorance of the Deity is an ignorance to which the soul is everlastingly condemned. By Him, however-now, at least, the Incomprehensible-by Him-assuming him as Spirit-that is to say, as not Matter-a distinction which, for all intelligible purposes, will stand well instead of a definition-by Him, then, existing as Spirit, let us content ourselves, to-night, with supposing to have been created, or made out of Nothing, by dint of his Volition-at some point of Space which we will take as a centre-at some period into which we do not pretend to inquire, but at all events immensely remote-by Him. (Poe, 1848: 28-29).

The wisdom implicit in the cosmic design has created the contours of these relations and implanted in all of them certain capacities that engender when left to their own causal powers, only beauty, only order. When we take these things into account, nature would appear to be more dignified than she normally looks. The only thing that one can expect then from her development and expansion is beauty and order (Fugate, 2012: 111).

According to Kant, the most compelling sign of the divine origin of the cosmos and the key indication of the genuine and absolute character of its creator is that it is capable of displaying dynamic harmony and perfection through its own necessary operations and thus, independently of any other divine action. Perfection, in other words, must be located in the universality of the mechanical laws that govern the cosmos (111).

\section{Origin, Black light and color: Poe and Olbers' Paradox}

In 1823 the German physicist Heinrich Wilhelm Olbers proposed the following paradox: if the size of the universe is infinite and stars are distributed throughout the universe, then we should see a star in any direction we look, and the night sky should be brightly-lit. And yet, the night sky is dark. Why? There is no satisfactory answer, but the best solution so far assumes that the universe has not existed for an indefinite time, but that it had a beginning (Alberto Rojo, 2011: electronic). "My general proposition, then, is this," writes Poe, "In the Original Unity of the First Thing lies the Secondary Cause of All Things, with the Germ of their Inevitable Annihilation" (1848: 8).

Therefore, our vision of the sky extends only as far as the distance that light travels in a time equal to the age of the universe. We do not see the stars that are beyond this distance because the light that they began to emit in their origin has not yet reached the Earth. The extension of the universe is infinite, or if not infinite, at least vast beyond all measure. The visible universe, on the other hand, is relatively small and does not manage to fill the sky with stars (Rojo, 2011 : electronic). The first person to imagine this solution was not a physicist or a astronomer, but Edgar Allan Poe, who in his book titled Eureka: a Prose Poem, published in 1848, tells us,"The only mode [...] we could comprehend the voids which our telescopes find in innumerable directions, would be by supposing the distance of the invisible background so immense that no ray from it has yet been able to reach us at all."(1848: 100). Amazing? Perhaps not. When science reaches the very edge of knowledge, it needs imagination more than anything else, and Poe's imagination was undoubtedly one of the most liberated and powerful of its time (Rojo, 2001: electronic). 
Through what we know of the propagation of light, we have direct proof that the more remote of the stars have existed, under the forms in which we now see them, for an inconceivable number of years [...] Of course, it will be immediately objected that since the light by which we recognize the nebulæ now, must be merely that which left their surfaces a vast number of years ago, the processes at present observed, or supposed to be observed, are, in fact, not processes now actually going on, but the phantoms of processes completed long in the Past-just as I maintain all these mass-constitutive processes must have been. To this I reply that neither is the now-observed condition of the condensed stars their actual condition, but a condition completed long in the Past; so that my argument drawn from the relative condition of the stars and the "nebulæ," is in no manner disturbed. (Poe, 1848: 90-91).

It is the subject who, in the final analysis, generates all that exists in his specific world: the Cosmos.

Fugate points out that this is not the only current that feeds and waters Poe's thinking. The distance that Schelling took from Kant's extreme subjectivism leads him to affirm a balance between matter and spirit, substance and form, Universe and primal oneness in the origin (which is also prescribed in the writer's conception of the Universe) (114 to 117).

Poe develops Eureka as a hybrid of philosophy and religion to answer questions about creation and death, the mysteries of the Universe. Eureka shifts (Vincelette, 2008: 38) in and out of physics and metaphysics in an attempt to establish a basis on which spirit (attraction) and matter (repulsion) can fuse. Curtis Brooks finds similarities between Poe and Empedocles, the pre-Socratic Greek philosopher who could be a source of Poe's ideas on attraction and repulsion (39).

Ljungquist argues that Poe uses sublimity in Eureka "as a metaphor for God's power" in the quest for revealed knowledge, the "soul's monomania in the search for the infinite." Poe's simplicity aligns with Burke's comments regarding the sublime, in which Burke states that "every thing great by its quantity must necessarily be, one, simple and entire."

(Vincelette, 2008: 39).

Poe establishes the extreme beauty of poetical simplicity - a theory that embraces the paradox of immensity and smallness (read simplicity) in spite of their being opposites. In Poe's cosmology, matter disperses, but this dispersion contains within itself potential energy, the power of the whole Universe in a given moment, Unity.

The assumption of absolute Unity in the primordial Particle includes that of infinite divisibility. Let us conceive the Particle, then, to be only not totally exhausted by diffusion into Space. From the one Particle, as a centre, let us suppose to be irradiated spherically -in all directions-to immeasurable but still to definite distances in the previously vacant space-a certain inexpressibly great yet limited number of unimaginably yet not infinitely minute atoms. (Poe, 1848: 31). 
Poe seeks to create an analogy between poetical creation and the creation of the Universe. There is no doubt that Poe was aware of the play on words implicit in the word Universe itself, which can be divided to give the sense of "a single verse." The etymological meaning of the root versus also shows that the word universe contains a built-in dialectic: the root versus can mean "turn toward" or "turn against." The word is a paradox in and of itself. The poet must operate on the personal level as an interpreter of God's poem, the universe, God's "conspiracy." The poet in Eureka uses his intuition for moral purposes-to decipher the seminal or original text, that of the cosmos, of which God is the author (Vincelette, $2008: 39-40$ ).

And now, let us see:-Our usual notions of irradiation-in fact all our distinct notions of it-are caught merely from the process as we see it exemplified in Light. Here there is a continuous outpouring of ray-streams, and with a force which we have at least no right to suppose varies at all. Now, in any such irradiation as thiscontinuous and of unvarying force-the regions nearer the centre must inevitably be always more crowded with the irradiated matter than the regions more remote. But I have assumed no such irradiation as this. (Poe, 1848: 53-54).

\section{CONCLUSIONS: A SKY STUDDED WITH SIGNS}

The scientific value of Eureka is evidently contingent. And yet Poe scholars have looked on in astonishment as some of the author's conjectures have been confirmed scientifically. With no scientific basis whatsoever on which to base his intuition, Poe deduced concepts of Physics and Astronomy that would turn out to be undeniable. His insight and his amazing imagination, as well as the philosophical wellsprings of his formation, would gain for him a much more ambitious place in posterity.

In fact, Poe was mistaken on a great many things, but he got it right on a few things that were very difficult to foresee. It has only become possible to verify his prescience with today's scientific and technological development. In this way we realize that certain artistic works (masterpieces of literature and/or the visual arts, or of any other expressive medium) can come to have a decisive impact on the generation of new fields of knowledge, discoveries and theoretical contributions in the world of science. They are ahead of their time and set the direction for changes. Such is the case of Eureka, a literary work written by Edgar Allan Poe in 1848, just a year before his death.

In Poe's time, for example, no one knew about the life cycle of stars; they were thought to be eternal. Nor was there any knowledge about the expansion of the Universe, or of relativity, or quantum mechanics. The speed of light was known, but it was assumed that the Universe was eternal and unchanging. There was no sense that it had a beginning Edwin Hubble would not corroborate that the Universe was expanding until the third decade of the 20th century. In Poe's time it was believed that the Universe was eternal and infinite in space and time.

The Big Bang as the origin of the Universe and the idea that it is expanding are the two concepts that Poe insists on the most throughout his text. In fact, they are the unifying threads that hold together all the other ideas he proposes; they are what make his thinking a visionary work of genius. "What you call The Universe is but his present expansive existence," he tells us at the end of Eureka (1848: 128). 
Remarkable thinking for a man of 1847. As we said before, the first scientific theory positing a Universe in expansion did not appear until seventy years later. And it was not until 1965, with the detection of generalized background radiation in all directions of space, which science recognized that the Universe was formed from the explosion of a concentration of matter-energy. Many years had to pass, and the necessary technology had to be developed, before the basic idea that Poe presented in his book could be confirmed.

Edgar Allan Poe's unimaginable but real worlds constitute a fascinating proposal not only because of the paradox enclosed in the very name Universe - a single verse, or a verse that contains within itself its opposite, the versus. They are also a proposal for fusing or amalgamating Art and Science in the way of Poe's reasoning. Except that in this case the co-creator, be it the artist or the scientist, acts within the very laboratory of life, which cannot be separated.

Poe is the narrator of a work that simultaneously discovers and reveals through intuition and imagination a Universe that is born, expands, and dies in the attempt. A Universe that is feasible through a very peculiar meta-physics that produces or processes its validity by linking the macro with the micro, the physical or material with the mental, the sublime and grand with what is apparently insignificant.

\section{REFERENCES}

Abrams, Meyer, H. (1971), The Mirror and the Lamp: Romantic Theory and the Critical Tradition, Oxford University Press, USA, c1953.

Cantalupo, Barbara (1990), "'Of or Pertaining to a Higher Power': Involution in Eureka," American Transcendental Quarterly, Vol. 4, N² 2 (June, 1990), p. 87.

Einstein, Albert (1985), Sobre la teoría de la relatividad y otras aportaciones científicas, (tr. José M. Álvarez Flores y Ana Goldar), Sarpe, Madrid.

EsplinEmron (2011),"Cosmopolitan Poe: AnIntroduction", en TheComparatist, Vol. 35, 2011, University of North Carolina Press, pp.198-210.

Fugate, Courtney (2012), "The German Cosmological Tradition and Poe's Eureka", in Edgar Allan Poe Review, Vol.13, N² Fall 2012, Penn State University Press, pp.109-134

Kierkegaard, Søren (1987a),Either/Or, Vol. I, ed. and trans. H. V. Hong and E. H. Hong, Princeton: Princeton University Press.

Kierkegaard, Søren(1987b),Either/Or, Vol. II, ed. and trans. H. V. Hong and E. H. Hong, Princeton: Princeton University Press.

Lee, Maurice, S. (2009), "Probably Poe", en American Literature, Vol.81, N², June 2009, Duke University Press, pp. 225-252.

Misner, Charles W., Thorne Kip.S. \& Wheeler John A. (1973), Gravitation, W.H.Freeman\& Co., New York, NY, c1970.

Ortega-Villaseñor, H (2003), “Andamiaje teórico para el estudio de la creatividad: el pensamiento popperiano en el arte y la ciencia", en Alpha: revista de artes, letras y filosofía, Vol. 19, pp. 235-250.

Peebles, Scott (2004), The Afterlife of Edgar Allan Poe, Rochester, N.Y.: Camden House. 2004.

Penón, José Luis (2013), “Ecos de Eureka, de Edgar Allan Poe en la literatura española de principios del S. XX", Journal of the College of Arts, Celtic Studies and Social Sciences, University College Dublin, Aigne, pp. 30-62.

Poe, Edgar A. (1848), Eureka: A Prose Poem, George P. Putman, New York, NY), c1848, 143 pp. La versión original puede consultarse también en línea (Project GutembergLicense): http://www.gutenberg.org/files/32037/32037-h/32037-h.htm. (Consulta de noviembre 15, 2013).

Poe, Edgar A. (1972), Eureka, (tr. Julio Cortázar, Alianza Editorial, Madrid), c1956, 129 pp.

Rachman, Stephen (2014), "Poe, the Arabesque, and Cosmology",Edgar Allan Poe Review; Vol. 15, Issue 1, pp. 1-19,. 
Rindler, Wolfgang (2001), Relativity. Special, General and Cosmological, New York, Oxford University Press,

Rojo, Alberto, G. (2010), Café científico, Pensar la ciencia entre todos (ciclo 2011), Programa de Divulgación Científica de SECYT, de la Universidad Nacional de Córdoba. Disponible en línea:http:/ / www.secyt.unc.edu.ar/cafecientifico/index.php?sec=201105cienciayarte\&col=1\&ci clo $=2011$

Rojo, Alberto, G. (2010), La física en la vida cotidiana, Siglo Veintiuno editores, Buenos Aires, c2007.

Rojo, Alberto, G. "Literatura y Ciencia. Cuatro Ejemplos de una Curiosa Intersección” (2001). Disponible en línea: http:/ /www.albertorojo.com/lyc/ . (Consulta de noviembre 15, 2013).

Stoltzfus, Ben (2012), "Magritte's Literary Affinities: Baudelaire and Poe", enIntertexts, Vol.16, N`2, Fall 2012, Texas Tech University Press, pp. 29-53.

Vincelette, Elizabeth (2008), "Beauty, Truth and the Word: The Prophecy and Theology of Poe's Eureka", en The Edgar Allan Poe Review, Vol. 9, No. 2 (Fall 2008), pp. 36-54, Published by: Penn State University Press, pp. 36-54.

$$
--0-
$$

A preliminary version of this article was presented at the 4th International Encounter of writers, researchers, editors and artists: "International Dialogue by Way of Serbia and International Artistic Expression," held in the city of Valjevo, Serbia on July 1-5, 2012, and attended by Humberto OrtegaVillaseñor, senior research and full time professor at the University of Guadalajara. The original title was 'Universe in Expansion,' and the presentation examined the link between literature, art and science as part of the Ortega-Villaseñor's research project "Word and Image (Static and Moving). Study of Creative Links and Their Impact on the Scientific and Technological Field from the Epistemic Perspective of Popper's Thinking," 2014-2016.Alonso S. Ortega González studied Physics at the University of Guadalajara and wrote his thesis on the topic of Cosmology. 